\title{
CENTRAL BANKING AND ECONOMIC TRANSITION
}

\author{
Nigel M Healey* \\ Janet Ilieva**
}

\begin{abstract}
The increasing independence of central banks from governments in a greater number of states is the central preoccupation of this study by Nigel M. Healey and Janet Ilieva from Manchester Metropolitan University. The writers point out the fact that this trend can be observed both in industrialized and in developing countries. The reforms that grant greater autonomy to central banks are realized alongside great economic transformations, especially in the central and eastern European countries where new monetary policies are established. The writers analyze the requirements for more autonomous central banks in the present day, and try to shed light upon the connection of high and persistent inflation to the necessity of greater indepenoence for central banks. In this study, the anatomy of the transition from a centrally-planned economy to a free market economy is presented, with an emphasis on the process of liberalization continuing since 1989 and its effects on monetary policies.
\end{abstract}

\section{Introduction}

Over the last decade, numerous countries have provided their central banks with greater legal independence from the government. This trend to increased central bank independence has been witnessed in both industrialised and developing countries (in particular, Latin America). Within the former socialist countries of central and eastern Europe (CEE), economic transition has also been accompanied by substantial central bank reforms granting autonomy in the setting and execution of monetary policy. There are three broad reasons for the establishment of more independent central banks.

First, central bank independence is justified theoretically by the existence of incentive constraints for politicians, which force dependent central banks to realise sub-optimally high rates of inflation. Since the seminal study by

* Professor Dr., Manchester Metropolitan University.

** Dr., Manchester Metropolitan University. 
Kydland and Prescott ${ }^{1}$, this inflation bias has been discussed primarily in terms of the 'credibility' problems of monetary policy caused by dynamic inconsistency ${ }^{2}$. In addition, the political independence of the central bank is aimed at protecting against partisan or electoral cycles in monetary policy, which in combination with ex ante uncertain election outcomes may, in turn, lead to sub-optimally high output volatility and contribute to a higher inflation bias ${ }^{3}$.

Secondly, a number of empirical studies claim that, in industrial countries, legal measures of central bank independence are inversely related to the average inflation ${ }^{4}$. In contrast, there appears to be no systematic relationship between central bank independence and economic growth ${ }^{5}$. In the case of developing countries, it appears that (in contrast to developed countries) legal independence of central banks is not a good measure of actual central bank independence. The negative correlation between central bank independence and inflation is confirmed, however, if so-called 'behavioural' indices like the actual turnover rates of central bank governors or the political vulnerability of the central bank governor are used to measure the degree of central bank independence ${ }^{6}$.

Thirdly, the inflationary track record of the Deutsche Bundesbank, which (prior to the establishment of the European Central Bank in 1999) was regarded as a particularly independent central bank, has been widely used as an exemplar of the benefits of giving central banks autonomy from governments.

These profound changes in attitudes to the role and functioning of central banks have coincided with the demise of central planning in central and eastern Europe (CEE). Since 1989, the marketisation and structural transformation of these economies has placed new demands on their central banks and led to experimentation with a variety of institutional frameworks for monetary control. The Baltic states, for example, have established currency boards, successfully stabilising their exchange rates and bringing inflation under control. In the four major states of CEE - Poland, the Czech Republic, Romanian and Bulgaria (which has also adopted a currency board since mid-1997) - the central bank has gained sufficient autonomy to achieve a substantial reduction in inflation. In many CIS countries, in contrast, the central banks continue to monetise large state deficits, fuelling inflation ${ }^{7}$.

The reform of central banking in CEE has taken place against the background of major structural reform and economic dislocation. This introduction sets the changes in central banking in a broader macroeconomic 
and institutional context. It provides an overview of the wider challenges facing the transition economies and the factors which have influenced the pace and shape of monetary policymaking across the region. After a brief review of the size and economic structure of the 28 'transition economies', this paper outlines the basic operation of centrally planned economies, highlighting the scale of the structural changes entailed by 'marketisation'. It documents the early phase of the transition process, when all the transition economies experienced a slump in output and hyperinflation following the breakdown of central planning and the liberalisation of prices. The paper then considers the main macroeconomic challenges involved in restoring stability and the microeconomic (or 'supply-side') challenges of privatisation, market liberalisation and legal reform. It finally assesses the progress of different countries over the ten years since the process began in 1989 and considers the outlook for monetary policymaking in the region.

\section{Central and eastern Europe versus the Commonwealth of Independent States}

The term 'communist bloc' was formerly used in the West to describe the countries that constituted the Soviet sphere of influence, implying a high degree of homogeneity between the 28 independent states that have subsequently emerged. In reality, the 'transition' states vary considerably, in terms of living standards (as measured by, for example, per capita GDP), economic structure, population size, history, religion and culture.

Table 1 gives some idea of the differences between the transition states. ${ }^{8}$ It shows the contrast in size, from Russia with a population of $147 \mathrm{~m}$ to Estonia with $1.5 \mathrm{~m}$. It highlights the vast gulf in relative living standards, from Slovenia with a per capita income (calculated in terms of purchasing power parity) of $\$ 9826$ to Tajikistan with just $\$ 200$. The importance of agriculture ranges from as little as 4-7\% of GDP in Slovenia, the Czech and Slovak Republics, Hungary and Poland to over $40 \%$ in Kyrgyzystan.

Table 1 also shows that despite the differences between individual states, it is possible to draw a broad distinction between the central and eastern European (CEE) states, here defined to include the three Baltic states of the former Soviet Union, and the twelve states of the Commonwealth of Independent States (CIS). Taken as a group, the CEE states have a generally higher per capita GDP, a lesser reliance on agriculture and, reflecting the labour shedding which is an inevitable consequence of enterprise restructuring, much higher rates of unemployment. 


\section{Table 1: An Overview of the Transition Economies}

\begin{tabular}{|c|c|c|c|c|c|}
\hline & $\begin{array}{l}\text { Population, } \\
\text { millions } \\
(1998)\end{array}$ & $\begin{array}{c}\text { Per Capita } \\
\text { GDP, } \\
\text { \$PPP (1998) }\end{array}$ & $\begin{array}{c}\text { Agriculture } \\
\text { as } \% \text { GDP } \\
\text { (1998) }\end{array}$ & $\begin{array}{l}\text { Industry } \\
\text { as \% GDP } \\
\text { (1998) }\end{array}$ & $\begin{array}{c}\text { Unemploy } \\
\text { ment (\%) } \\
\text { (1998) }\end{array}$ \\
\hline \multicolumn{6}{|l|}{ CEE Countries: } \\
\hline Albania & 3.2 & $708^{*}$ & 62.6 & $12.2^{\star \star}$ & $12.4^{* *}$ \\
\hline Bulgaria & 8.3 & 1700 & 23.3 & 29.4 & 12 \\
\hline Croatia & 4.53 & 4477 & $10.0^{\star \star \star}$ & $23.6^{\star \star \star}$ & 17.6 \\
\hline Czech Republic & 10.3 & 5347 & 4.8 & 36.5 & 7.5 \\
\hline Estonia & 1.45 & $3230^{*}$ & $6.3^{*}$ & $19.4^{*}$ & 9.6 \\
\hline FYR Macedonia & 2.0 & $1663^{*}$ & $10.8^{\star}$ & $19^{\star}$ & $36.0^{*}$ \\
\hline Hungary & 10.12 & 4727 & $5.8^{\star}$ & $25.0^{*}$ & 7.8 \\
\hline Latvia & 2.5 & 2520 & 6.7 & 26.0 & 9.2 \\
\hline Lithuania & 3.7 & 2832 & $12.8^{*}$ & $24.4^{\star}$ & 6.4 \\
\hline Poland & 38.7 & 4000 & $6.0^{\star \star *}$ & $27.1^{* * *}$ & 10.4 \\
\hline Romania & 22.5 & 1697 & 16.0 & 31.7 & 10.3 \\
\hline Slovak Republic & 5.4 & 3793 & $4.8^{*}$ & $28.2^{*}$ & 11.9 \\
\hline Slovenia & 2.0 & 9826 & 4.1 & 38.9 & 14.5 \\
\hline \multicolumn{6}{|l|}{ CIS Countries: } \\
\hline Armenia & 3.7 & 500.2 & 33.2 & 23.4 & 9.9 \\
\hline Azerbaijan & 7.62 & 540 & $20.0^{*}$ & $24.8^{*}$ & $19.3^{*}$ \\
\hline Belarus & 10.2 & 1400 & 12.7 & 38.4 & 2.3 \\
\hline Georgia & 5.38 & 910 & 26.2 & 9.6 & 14.0 \\
\hline Kazakhstan & 15.3 & 1463 & 8.8 & 22.5 & $4.1^{*}$ \\
\hline Kyrgyzstan & 4.6 & $366^{*}$ & $43.4^{*}$ & $15.5^{*}$ & $3.2^{*}$ \\
\hline Moldova & 4.3 & 385.9 & $30.0^{\star}$ & $29.0^{*}$ & $1.6^{*}$ \\
\hline Russia & 146.7 & 1867 & 6.5 & 42.7 & 12.4 \\
\hline Tajikistan & 6.2 & 200 & $27.6^{\star}$ & $19.5^{\star}$ & 3.1 \\
\hline Turkmenistan & 4.8 & 403 & $19.8^{*}$ & $44.3^{\star}$ & $\mathrm{n} / \mathrm{a}$ \\
\hline Ukraine & 50.1 & 840 & 11.8 & 24.6 & 3.7 \\
\hline Uzbekistan & $23.6^{\star}$ & $611^{\star}$ & $29.0^{*}$ & $19.0^{\star}$ & 0.6 \\
\hline
\end{tabular}

Source: EBRD (1999), Transition report: update, London: European Bank for Reconstruction and Development.

$*=1997$ figure, ${ }^{* *}=1996$ figure, ${ }^{* * *}=1995$ figure. 


\section{The Operation of the Command Economy}

Despite the differences between the CEE and the CIS states, both groups started the transition process with an all pervasive central planning system, often termed a 'command economy'. The command economy dominated every aspect of life, instructing factories where to buy their inputs, how much to pay their workers, how much to produce and where to sell their output; individuals were trained in specialist schools and universities and directed to work at specific factories, which provided their wages, houses, health care; the national plan informed the banking system how much to lend to which factories and how much cash to print to pay wages.

As a theoretical concept, central planning was very elegant. Using 'input-output' analysis (a planning framework which calculated the inputs required for each factory in order for it to deliver its planned outputs to the next stage in the production process), the planning ministry could calculate precisely how much labour, capital and raw materials each enterprise required to achieve its production targets. The various production targets for raw materials and intermediate and final products all fitted together to ensure a perfectly balanced expansion of the economy. Input and output prices were precisely set to ensure that all firms could pay their wage bills and repay loans from the national bank, while at the same time pricing consumer goods to encourage consumption of socially desirable goods (eg, books, ballet, theatre, public transport, etc) and discourage consumption of politically unfavoured goods (eg, international telephone calls, cars, luxury goods).

The overall national plan was thus internally consistent. If each of the enterprises achieved its production targets, there could not be, by definition, shortages or bottlenecks in the economy. There would be full employment, with everyone working in an enterprise for which he/she had been specifically trained at school and university. The total wage bill for the economy, which was paid in cash, would be sufficient to buy all the consumer goods produced. There would be zero inflation and all the country's citizens would have access to housing, education and health care.

While central planning ultimately failed in CEE and the CIS, the immanent causes remain a matter of controversy. For present purposes, it is sufficient to note that, whatever the triggering factor, the precipitous collapse of the Soviet planning system in the period between 1989-91 left the transition economies ill-prepared for managing is an environment of rapid structural change, social upheaval and reintegration into the global economy. 


\section{The Early Stages of the Transition Process}

The decades of central planning meant that the transition economies began the reform process without functioning markets for labour, goods or capital. All three had been allocated by the central planner, in accordance with an internally coherent economic plan. Because all the means of production had been in state hands, there was, moreover, no legislative framework for the enforcement of property rights, the valuation and disposal of assets or the liquidation of unprofitable enterprises. Nor in a system of directed labour was there any official unemployment and, hence, no need for a social security system. As noted above, social welfare was provided by enterprises, with the central planners setting their aggregate employment equal to the size of the labour force and services like education, health care and housing being provided by the enterprises to their employees. Banks in the central planning system were bookkeeping operations, allocating credit according to the demands of the plan rather than objective risk assessments and capital markets were nonexistent. The challenge for the transition states at the end of the 1980s was to build a modern market economy on these foundations.

The early 1990s ushered in a period of economic crisis in the transition economies of CEE and the CIS. The breakdown of central plan discipline and the collapse of COMECON trade, taken together with the highly concentrated, vertically integrated nature of production (particularly in the CIS), led to an early collapse in production across the region. (see Table 2).

Recovery began first in CEE, with all countries except Bulgaria showing positive growth in 1996. Nevertheless, only in Poland has recent growth been sufficient to regain the losses of the early years: in all other states, output in 1998 remains at or below the level in 1989. Recovery in the CIS countries started later and has been more hesitant. For the CIS countries as a group, output in 1998 remains at only $57 \%$ of its 1989 level.

With national and regional governments heavily reliant on 'profit' and 'turnover' taxes on enterprises for state revenues, the early recession led to a sharp contraction of the tax base. In the absence of developed capital markets, which in market economies offer governments the opportunity of selling securities to finance themselves in a non-inflationary way, the resulting budget deficits were financed by printing cash through the central bank. Inflationary pressures were further compounded in many transition economies by the state's attempts to avoid wholesale job losses by granting heavy subsidies to lossmaking enterprises. Whether these were provided by the state directly, thereby adding to its budget deficit, or in the form of 'soft' loans from the central bank, the result in both cases was to further fuel the rate of growth of the money supply. The slump in output was thus accompanied by hyperinflation in many 
Table 2: Recession and Recovery in Transition Economies (\% annual change in GDP)

\begin{tabular}{|c|c|c|c|c|c|c|c|c|c|}
\hline & 1991 & 1992 & 1993 & 1994 & 1995 & 1996 & 1997 & 1998 & $\begin{array}{c}1998 \\
1989=100\end{array}$ \\
\hline \multicolumn{10}{|l|}{ CEE Countries: } \\
\hline Albania & -28 & -7.2 & 9.6 & 9.4 & 8.9 & 9.1 & -7.0 & 8.0 & 86 \\
\hline Bulgaria & -12 & -7.3 & -1.5 & 1.8 & 2.1 & -10.9 & -6.9 & 2.5 & 65 \\
\hline Croatia & -20 & -11.7 & -8.0 & 5.9 & 6.8 & 6.0 & 6.5 & 2.5 & 78 \\
\hline Czech Republic & -14 & -3.3 & 0.6 & 3.2 & 6.4 & 3.9 & 1.0 & -2.7 & 95 \\
\hline Estonia & -11 & -14.2 & -9.0 & -2.0 & 4.3 & 4.0 & 11.4 & 4.0 & 76 \\
\hline FYR Macedonia & -12 & -21.1 & -9.1 & -1.8 & -1.2 & 0.8 & 1.5 & 3.0 & 58 \\
\hline Hungary & -12 & -3.1 & -0.6 & 2.9 & 1.5 & 1.3 & 4.4 & 5.0 & 95 \\
\hline Latvia & -8 & -34.9 & -15 & 0.6 & -0.8 & 3.3 & 6.5 & 4.0 & 58 \\
\hline Lithuania & -13 & -21.3 & -16 & -9.8 & 3.3 & 4.7 & 6.1 & 4.0 & 64 \\
\hline Poland & -7 & 2.6 & 3.8 & 5.2 & 7.0 & 6.1 & 6.9 & 4.8 & 117 \\
\hline Romania & -13 & -8.8 & 1.5 & 3.9 & 7.1 & 4.1 & -6.6 & -7.3 & 76 \\
\hline Slovak Republic & -15 & -6.5 & -3.7 & 4.9 & 6.9 & 6.6 & 6.5 & 4.4 & 100 \\
\hline Slovenia & -8 & -5.5 & 2.8 & 5.3 & 4.1 & 3.3 & 3.8 & 4.0 & 103 \\
\hline All CEE* & -11 & -3.8 & 0.4 & 3.9 & 5.5 & 4.0 & 3.6 & 2.3 & 98 \\
\hline \multicolumn{10}{|l|}{ CIS Countries: } \\
\hline Armenia & -11 & -52.6 & -14.8 & 5.4 & 6.9 & 5.8 & 3.1 & 7.2 & 41 \\
\hline Azerbaijan & -1 & -22.6 & -23.1 & -20 & -12 & 1.3 & 5.8 & 10.1 & 44 \\
\hline Belarus & -1 & -9.6 & -7.6 & -13 & -10 & 2.8 & 10.4 & 8.0 & 77 \\
\hline Georgia & -14 & -44.8 & -25.4 & -11 & 2.4 & 10.5 & 11.0 & 2.9 & 33 \\
\hline Kazakhstan & -13 & -2.9 & -9.2 & -13 & -8.2 & 0.5 & 2.0 & -2.5 & 61 \\
\hline Kyrgyzstan & -5 & -19 & -16 & -20 & -5.4 & 7.1 & 10.4 & 1.8 & 61 \\
\hline Moldova & -18 & -29.1 & -1.2 & -31 & -3.0 & -8.0 & 1.3 & -8.6 & 32 \\
\hline Russia & -13 & -14.5 & -8.7 & -13 & -4.1 & -3.5 & 0.8 & -4.6 & 55 \\
\hline Tajikistan & -7 & -29 & -11 & -19 & -13 & -4.4 & 1.7 & 4.0 & 41 \\
\hline Turkmenistan & -5 & -5.3 & -10 & -19 & 8.2 & -8.0 & -26 & 4.2 & 44 \\
\hline Ukraine & -9 & -13.7 & -14.2 & -23 & -12 & -10.0 & -3.2 & -1.7 & 37 \\
\hline Uzbekistan & -1 & -11.1 & -2.3 & -4.2 & -0.9 & 1.6 & 2.4 & 2.0 & 88 \\
\hline All CIS ${ }^{*}$ & -12 & -14.1 & -9.3 & -14 & -5.1 & -3.5 & 0.9 & -3.5 & 55 \\
\hline
\end{tabular}

Source: EBRD (1999), Transition report: update, London: European Bank for Reconstruction and Development. (* averages weighted by 1997 real GDP). 
transition states, as price liberalisation brought repressed inflation out into the open. Table 3 shows the inflation rates suffered by countries in the region in recent years.

\begin{tabular}{|c|c|c|c|c|c|c|c|c|}
\hline \multicolumn{9}{|c|}{$\begin{array}{l}\text { Table 3: The Inflationary Price of Transition } \\
\text { (\% annual change in retail prices, end-year) }\end{array}$} \\
\hline & 1991 & 1992 & 1993 & 1994 & 1995 & 1996 & 1997 & 1998 \\
\hline \multicolumn{9}{|l|}{ CEE Countries: } \\
\hline Albania & 104.0 & 236.6 & 30.9 & 15.8 & 6.0 & 17.4 & 42.1 & 8.7 \\
\hline Bulgaria & 339.0 & 79.4 & 63.8 & 121.9 & 32.9 & 310.8 & 578.6 & 1.0 \\
\hline Croatia & 249.0 & 938.2 & 1149.0 & -3.0 & 3.8 & 3.4 & 3.8 & 5.4 \\
\hline Czech Republic & 52.0 & 12.7 & 18.2 & 9.7 & 7.9 & 8.6 & 10.0 & 6.8 \\
\hline Estonia & 304.0 & 953.5 & 35.6 & 42.0 & 29.0 & 15.0 & 12.4 & 6.8 \\
\hline FYR Macedonia & 115.0 & 1935.0 & 241.8 & 55.0 & 9.0 & -0.6 & 2.6 & -2.4 \\
\hline Hungary & 32.0 & 21.6 & 21.1 & 21.2 & 28.3 & 19.3 & 18.4 & 10.3 \\
\hline Latvia & 262.0 & 959.0 & 35.0 & 26.0 & 23.1 & 13.1 & 7.0 & 2.8 \\
\hline Lithuania & 345.0 & 1161.1 & 188.8 & 45.0 & 35.5 & 13.1 & 8.5 & 2.4 \\
\hline Poland & 60.0 & 2.6 & 37.6 & 29.4 & 21.6 & 18.5 & 13.2 & 8.6 \\
\hline Romania & 223.0 & -8.8 & 295.5 & 61.7 & 27.8 & 56.9 & 151.4 & 40.6 \\
\hline Slovak Republic & 58.0 & -6.5 & 25.1 & 11.7 & 7.2 & 5.4 & 6.4 & 5.6 \\
\hline Slovenia & 247.0 & -5.5 & 22.8 & 19.5 & 9.0 & 9.0 & 8.8 & 6.5 \\
\hline \multicolumn{9}{|l|}{ CIS Countries: } \\
\hline Armenia & 25.0 & -52.6 & 10896.0 & 1885.0 & 31.9 & 5.8 & 21.8 & -1.3 \\
\hline Azerbaijan & 126.0 & -22.6 & 1294.0 & 1788.0 & 84.5 & 65 & 0.3 & -7.6 \\
\hline Belarus & 93.0 & 1559.0 & 1996.0 & 1960.0 & 244.0 & 39.0 & 63.0 & 181.7 \\
\hline Georgia & 131.0 & 1176.9 & 7487.9 & 6474.4 & 57.4 & 14.3 & 7.2 & 10.7 \\
\hline Kazakhstan & 150.0 & 2984.1 & 2169.0 & 1160.0 & 60.4 & 28.6 & 11.3 & 1.9 \\
\hline Kyrgystan & 170.0 & 1259.0 & 1363.0 & 95.7 & 31.9 & 35.0 & 14.7 & 18.3 \\
\hline Moldova & 151.0 & 2198.0 & 837.0 & 116.0 & 23.8 & 15.1 & 11.2 & 18.2 \\
\hline Russia & 144.0 & 2506.1 & 840.0 & 204.4 & 128.6 & 21.8 & 10.9 & 84.5 \\
\hline Tajikistan & 204.0 & 1364.0 & 7343.7 & 1.1 & 2133.3 & 40.5 & 163.6 & 2.7 \\
\hline Turkmenistan & 155.0 & 644.0 & 9750.0 & 1328.0 & 1262.0 & 446.0 & 21.5 & 19.8 \\
\hline Ukraine & 161.0 & 2730.0 & 10155.0 & 401.0 & 182.0 & 39.7 & 10.1 & 20.0 \\
\hline Uzbekistan & 169.0 & 910.0 & 885.0 & 1281.0 & 117.0 & 64.0 & 50.0 & 40.0 \\
\hline
\end{tabular}

Source: EBRD (1999), Transition report: update, London: European Bank for Reconstruction and Development. 
Clearly, the challenges facing the transition economies at the start of the process were profound and had both macroeconomic and microeconomic dimensions. At the macroeconomic level, the main priority was to construct new instruments of fiscal and monetary policy and thereby stabilise economies suffering from collapsing output and spiralling prices. Under the former system, the central planners could set both production levels and final producer prices directly through the national plan. In the new emerging market economies, they needed to construct the tools to achieve these goals at the macroeconomic level through indirect means, by changing taxes and government spending and by altering interest rates and managing the exchange rate. At the microeconomic level, the priority was to transform an economy of large, state-owned enterprises (SOEs) into competitive, private companies capable of trading globally.

\section{Macroeconomic Reform}

Governments in market economies use two main sets of policy instruments to indirectly influence economic activity: fiscal policy æ the use of taxes and public spending; and monetary policy $æ$ the control of interest rates (and the exchange rate). Neither set of policy instruments exists in the same form in a command economy. In the central planning system, taxes were levied on SOEs, normally in the form of 'turnover taxes' (ie, taxes on the enterprises' sales revenue or turnover), and on individuals in the form of income tax. These taxes ensured that the government could, as in a market economy, finance the army and other executive functions (eg, law and order) that did not fund their activities by generating their own sales revenues. These taxes and associated government spending, like the configuration of input and output prices, were an integral part of the national plan and were set to ensure its internal consistency. Significantly, many social services that are provided by the state in market economies like public housing, public transport, pre-school education, vocational training and health care were often provided by SOEs to their employees and families and financed out of the enterprises' operating surpluses.

As a consequence, the tax base at the start of the process in most transition economies was small relative to market economies (since so many social services were financed directly by SOEs) and tax and spending decisions were part of the broader process of national planning. In contrast, in a market economy, governments need to raise taxes to finance the whole range of public goods and social services, at the same time setting the balance between taxes and public spending (ie, the budget deficit or surplus) in order to stabilise aggregate demand and output.

Similarly, in a command economy, there is a unified financial system, with different branches of the national bank acting as a bookkeeper for 
transactions between companies in different sectors and providing deposit, but not lending, facilities (through a national savings branch) to the general population. Credit was allocated by the national bank's sectoral branches according to the requirements of the national plan. Interest rates played no part in the allocation of, or demand for, credit. Lending facilities for retail customers were unknown. Domestic currencies were not freely convertible, but could (with official approval) be exchanged for foreign currencies through the national bank at artificial exchange rates depending upon the purpose (a favourable rate for exporters, a higher, penal rate for importers). There were no financial markets of the sort recognisable in market economies.

Because the creation of financial markets which can price risk and allocate savings to projects and companies with the best, risk-adjusted returns is essential to the transition process (see below), microeconomic reform fundamentally alters the role of the national bank. In the presence of financial markets made by private banks and financial institutions and used to channel savings to private companies, the interest rate (and the exchange rate) become powerful tools for influencing saving, borrowing and spending in the economy as a whole.

\subsection{Fiscal Policy Reform}

Because the system of taxes and government spending had been constructed around the needs of central planning, the fiscal policy instruments at the disposal of governments in the early stages of the transition process were ill-suited to dealing with the emerging markets economies. Fiscal policy was beset by two overriding problems. First, the tax base was small and not set up to deal with the tax affairs of small, private companies. As the central plan collapsed and SOEs output and turnover slumped, the revenue from turnover taxes fell sharply. In the economic chaos that followed, many SOEs switched to bartering their outputs for inputs; other profitable SOEs took advantage of the confusion and simply stopped paying taxes. Attempts to bolster tax revenues by introducing new tax regimes for de novo private companies often foundered, because tax rates were set so high that the companies evaded taxes. The old tax systems in many countries proved unable to deal with the changing structure of economic activity and there was a slump in tax revenues as more and more economic activity shifted into the 'informal' or 'hidden' economy (see Table 4).

At the same time, the pressure on government spending increased. Many SOEs quickly found themselves in genuine financial distress, unable to pay their workforces or continue to fund the social services they had traditionally provided. Many of the associated 'social assets' (public housing, schools, hospitals, public transport systems) were taken into local government control. With widespread popular resistance to attempts to levy user charges which 
more closely approximated the true opportunity costs of providing these services, this 'nationalisation' of social services, particularly in the former Soviet Union, added to government spending. Even more significantly, there was intense political pressure on governments to 'bail out' failing SOEs, by extending them state subsidies to allow them to pay wages. The fear of social unrest, prompted by episodic strikes and demonstrations by powerful groups of workers (eg, miners, shipyard workers), encouraged many transition governments to give large subsidies to their SOEs.

\section{Table 4: Share of the Unofficial Economy in GDP}

\begin{tabular}{|l|r|r|r|r|r|r|r|}
\hline & 1989 & 1990 & 1991 & 1992 & 1993 & 1994 & 1995 \\
\hline CEE Countries: & & & & & & & \\
\hline Bulgaria & $\mathbf{2 2 . 8}$ & $\mathbf{2 5 . 1}$ & $\mathbf{2 3 . 9}$ & $\mathbf{2 5 . 0}$ & $\mathbf{2 9 . 9}$ & $\mathbf{2 9 . 1}$ & $\mathbf{3 6 . 2}$ \\
\hline Czech Republic & $\mathbf{6 . 0}$ & $\mathbf{6 . 7}$ & $\mathbf{1 2 . 9}$ & $\mathbf{1 6 . 9}$ & $\mathbf{1 6 . 9}$ & $\mathbf{1 7 . 6}$ & $\mathbf{1 1 . 3}$ \\
\hline Estonia & 12.0 & 19.9 & 26.2 & 25.4 & 24.1 & 25.1 & 11.8 \\
\hline Hungary & 27.0 & 28.0 & 32.9 & 30.6 & 28.5 & 27.7 & 29.0 \\
\hline Latvia & 12.0 & 12.8 & 19.0 & 34.3 & 31.0 & 34.2 & 35.3 \\
\hline Lithuania & 12.0 & 11.3 & 21.8 & 39.2 & 31.7 & 28.7 & 21.6 \\
\hline Poland & $\mathbf{1 5 . 7}$ & $\mathbf{1 9 . 6}$ & $\mathbf{2 3 . 5}$ & $\mathbf{1 9 . 7}$ & $\mathbf{1 8 . 5}$ & $\mathbf{1 5 . 2}$ & $\mathbf{1 2 . 6}$ \\
\hline Romania & $\mathbf{2 2 . 3}$ & $\mathbf{1 3 . 7}$ & $\mathbf{1 5 . 7}$ & $\mathbf{1 8 . 0}$ & $\mathbf{1 6 . 4}$ & $\mathbf{1 7 . 4}$ & $\mathbf{1 9 . 1}$ \\
\hline Slovak Republic & 6.0 & 7.7 & 15.1 & 17.6 & 16.2 & 14.6 & 5.8 \\
\hline CIS Countries: & & & & & & & \\
\hline Azerbaijan & 12.2 & 21.9 & 22.7 & 39.2 & 51.2 & 58.0 & 60.6 \\
\hline Belarus & 12.0 & 15.4 & 16.6 & 13.2 & 11.0 & 18.9 & 19.3 \\
\hline Georgia & 12.0 & 24.9 & 36.0 & 52.3 & 61.0 & 63.5 & 62.6 \\
\hline Kazakhstan & 12.0 & 17.0 & 19.7 & 24.9 & 27.2 & 34.1 & 34.3 \\
\hline Moldova & 12.0 & 18.1 & 27.1 & 37.3 & 34.0 & 39.7 & 35.7 \\
\hline Russia & 12.0 & 14.7 & 23.5 & 32.8 & 36.7 & 40.3 & 41.6 \\
\hline Ukraine & 12.0 & 16.3 & 25.6 & 33.6 & 38.0 & 45.7 & 48.9 \\
\hline Uzbekistan & 12.0 & 11.4 & 7.8 & 11.7 & 10.1 & 9.5 & 6.5 \\
\hline
\end{tabular}

Source: Johnson, Kaufmann and Shleifer (1997)

In the late 1990 s, the fiscal situation in most countries is starting to stabilise, as new, market-oriented taxes begin to take effect (see Table 5). Budget deficits have gradually declined, particularly in CEE, to levels common in advanced market economies. Extending the tax base has not been easy, however, as companies used to trading in the informal economy have sought to resist the introduction of new company taxes and systems of value-added taxes (VAT). 
Table 5: General government budget balances ( $\%$ of GDP)

\begin{tabular}{|c|c|c|c|c|c|c|c|}
\hline & 1992 & 1993 & 1994 & 1995 & 1996 & 1997 & 1998 \\
\hline \multicolumn{8}{|l|}{ CEE Countries: } \\
\hline Albania & -20.3 & $-14,4$ & -12.4 & -10.3 & -12.1 & -12.7 & -10.7 \\
\hline Bulgaria & -5.2 & -10.9 & -5.8 & -6.4 & -13.4 & -2.6 & 1.0 \\
\hline Croatia & -3.9 & -0.8 & 1.6 & -0.9 & 0.4 & -1.3 & 0.5 \\
\hline Czech Republic & -3.1 & 0.5 & -1.2 & -1.8 & -1.2 & -2.1 & -2.7 \\
\hline Estonia & -0.3 & -0.7 & 1.3 & -1.3 & -1.5 & 1.9 & -0.3 \\
\hline FYR Macedonia & -9.6 & -13.8 & -2.9 & -1.2 & -0.5 & -0.4 & -1.7 \\
\hline Hungary & -7.6 & -8.9 & -8.6 & -6.2 & -3.1 & -4.9 & -4.6 \\
\hline Latvia & -0.8 & 0.6 & -4.0 & -3.3 & -1.4 & 1.3 & 0.1 \\
\hline Lithuania & 0.5 & -3.3 & -5.5 & -4.5 & -4.5 & -1.8 & -6.0 \\
\hline Poland & -6.7 & -3.1 & -3.1 & -2.8 & -3.3 & -3.1 & -3.0 \\
\hline Romania & -4.6 & -0.4 & -1.9 & -2.6 & -4.0 & -3.6 & -5.5 \\
\hline Slovak Republic & $\mathrm{N} / \mathrm{a}$ & -7.0 & -1.3 & 0.2 & -1.9 & -3.8 & -5.6 \\
\hline Slovenia & 0.2 & 0.1 & -0.3 & -0.5 & -0.2 & -1.7 & -1.4 \\
\hline \multicolumn{8}{|l|}{ CIS Countries: } \\
\hline Armenia & -13.9 & -54.7 & -10.5 & -11.0 & -9.3 & -5.9 & -5.2 \\
\hline Azerbaijan & 2.8 & -15.3 & -12.1 & -4.9 & -2.8 & -1.7 & -4.1 \\
\hline Belarus & 0.0 & -1.9 & -2.5 & -1.9 & -1.6 & -0.7 & -1.0 \\
\hline Georgia & -25.4 & -26.2 & -7.4 & -4.5 & $-4,4$ & -3.8 & -4.4 \\
\hline Kazakhstan & -7.3 & -4.1 & -7.5 & -2.7 & -4.7 & -6.8 & -8.0 \\
\hline Kyrgystan & -17.4 & -14.2 & -11.6 & -17.0 & -9.0 & -9.4 & -9.8 \\
\hline Moldova & -26.2 & -7.4 & -8.7 & -5.7 & -6.7 & -7.5 & -7.5 \\
\hline Russia & -4.1 & -7.4 & -9.0 & -5.7 & -8.3 & -5.0 & -3.6 \\
\hline Tajikistan & -28.4 & -23.6 & -10.2 & -11.2 & -5.8 & -3.3 & -3.2 \\
\hline Turkmenistan & 13.2 & -0.5 & -1.4 & -1.6 & -0.2 & 0.01 & -4.0 \\
\hline Ukraine & -25.4 & -16.2 & -9.1 & -4.4 & -3.2 & -5.6 & -2.5 \\
\hline Uzbekistan & -18.4 & -10.4 & -6.1 & -4.1 & -7.3 & -2.3 & -3.8 \\
\hline
\end{tabular}

Source: EBRD (1999), Transition report: update, London: European Bank for Reconstruction and Development. 


\subsection{Monetary Policy Reform}

In a command economy, the national bank performs many of the functions of the central bank and the commercial banking system in a market economy, controlling the money supply, taking deposits from the general public and lending money to enterprises. The essential difference is that these activities are all part of a wider national economic plan: money emission, in the form of bank notes, is set via the treasury plan to ensure that enterprises can pay their workers; and a separate credit plan allocates loans to enterprises to support their investment and finance stocks and work-in-progress. In the former communist countries, the national bank was normally structured into functional areas: the national bank which performed a coordinating role and liaised directly with the planning ministry, several sectoral banks (agriculture, industry, etc) which managed the accounts of enterprises within their designated sector, an investment bank which made loans to enterprises for capital investment and a national savings bank, which held the deposits of the general public.

In this system, there were, in effect, two parallel monetary systems, one cash-based, one credit-based. In the cash economy, the national bank, as part of the planning process, set the volume of cash to be printed within a given time period. The production plan for each enterprise specified the amount of cash they could draw from their sectoral bank to pay wages; all wages and salaries were paid in cash. The general public then used their cash wages to buy goods and services and the state shops redeposited their cash takings in the national bank; household savings were deposited in the national savings bank. In the credit economy, the national plan set limits on the amount each enterprise could borrow from its sectoral or investment bank to finance investment and stocks. Inter-enterprise payments were all made by transfers between their accounts in the national banking system. Credits were not convertible into cash, so the two systems were separate, although integrated through the national plan.

This feature of the command economy gave rise to curious monetary problems. It was possible, for example, for the two monetary systems to become misaligned. For example, if the national bank increased the cash issue to allow enterprises to pay higher wages, there could be increased demand for goods by households. At the same time, there may be restrictions on credit availability, so that enterprises could not expand production. Excess demand for consumer goods could co-exist with excess supply of producer goods.

The immediate priority for the post-communist countries was to integrate the cash and credit systems and create a 'two-tier' financial system, in which 
the national bank could assume the responsibilities of a conventional central bank, setting interest rates and ensuring the viability of the system as a whole, and a lower tier of commercial banks could take deposits and make loans on market terms. In the former Soviet republics, there was an additional decision to be taken, namely whether to remain in monetary union with Russia after independence, or to secede and establish their own currency. In the event, the political difficulties of maintaining monetary ties with Russia during the turbulence of the transition process forced the issue and even those states which might have preferred to remain within the rouble zone introduced their own national currencies.

The restructuring of the national bank system was achieved fairly quickly, with most countries choosing to privatise the sectoral, investment and savings divisions of the national bank and allowing new joint-stock banks to be created. The core of the national bank which remained in state control was normally reconstituted as a central bank and, in most countries, given a high degree of legal autonomy from the government, along with a mandate to manage monetary conditions in the pursuit of price stability. Indeed, the constitution of the Bundesbank was widely used as model for designing the new central banks of CEE and the CIS - the major CEE countries were, as measured by legal indices, at least as independent as that of the Bundesbank.

\section{Table 6: Broad Money Growth (\% change pa)}

\begin{tabular}{|l|r|r|r|r|r|r|r|r|}
\hline & 1991 & 1992 & 1993 & 1994 & 1995 & 1996 & 1997 & 1998 \\
\hline CEE Countries: & & & & & & & & \\
\hline Albania & 104.4 & 152.7 & 75.0 & 40.6 & 51.8 & 43.8 & 28.4 & 19.7 \\
\hline Bulgaria & $\mathbf{1 1 0 . 0}$ & $\mathbf{5 3 . 6}$ & $\mathbf{4 7 . 6}$ & $\mathbf{7 8 . 6}$ & $\mathbf{3 9 . 6}$ & $\mathbf{1 2 4 . 5}$ & $\mathbf{3 5 9 . 3}$ & $\mathbf{3 . 7}$ \\
\hline Croatia & $\mathrm{n} / \mathrm{a}$ & $\mathrm{n} / \mathrm{a}$ & $\mathrm{n} / \mathrm{a}$ & $\mathbf{1 1 1 . 9}$ & 24.6 & 37.9 & 20.9 & -1.5 \\
\hline Czech Republic & $\mathbf{2 6 . 8}$ & $\mathbf{2 0 . 7}$ & $\mathbf{1 9 . 8}$ & $\mathbf{1 9 . 9}$ & $\mathbf{1 9 . 8}$ & $\mathbf{9 . 2}$ & $\mathbf{1 0 . 1}$ & $\mathbf{5 . 2}$ \\
\hline Estonia & $\mathrm{n} / \mathrm{a}$ & 59.0 & 93.0 & 40.0 & 34.0 & 36.0 & 42.0 & 0.0 \\
\hline FYR Macedonia & $\mathrm{n} / \mathrm{a}$ & $\mathrm{n} / \mathrm{a}$ & $\mathrm{n} / \mathrm{a}$ & $\mathrm{n} / \mathrm{a}$ & -2.7 & -0.1 & 24.5 & $\mathrm{~N} / \mathrm{a}$ \\
\hline Hungary & 35.7 & 27.6 & 15.7 & 13.0 & 20.1 & 22.3 & 19.4 & 15.5 \\
\hline Latvia & 153.0 & 169.9 & 84.1 & 47.7 & -23.1 & 19.9 & 38.7 & 5.9 \\
\hline Lithuania & 143.0 & 245.3 & 100.2 & 63.0 & 28.9 & -3.5 & 34.1 & 14.5 \\
\hline Poland & $\mathbf{3 7 . 0}$ & $\mathbf{5 7 . 5}$ & $\mathbf{3 6 . 0}$ & $\mathbf{3 8 . 2}$ & $\mathbf{3 4 . 9}$ & $\mathbf{2 9 . 4}$ & $\mathbf{2 9 . 1}$ & $\mathbf{2 5 . 0}$ \\
\hline Romania & $\mathbf{1 0 1 . 2}$ & $\mathbf{7 9 . 6}$ & $\mathbf{1 4 1 . 0}$ & $\mathbf{1 3 8 . 1}$ & $\mathbf{7 1 . 6}$ & $\mathbf{6 6 . 4}$ & $\mathbf{7 5 . 9}$ & $\mathbf{4 8 . 9}$ \\
\hline Slovak Republic & $\mathrm{n} / \mathrm{a}$ & $\mathrm{n} / \mathrm{a}$ & 16.8 & 20.1 & 19.2 & 16.5 & 9.1 & 2.6 \\
\hline Slovenia & $\mathrm{n} / \mathrm{a}$ & 131.6 & 64.2 & $\mathbf{5 0 . 8}$ & 32.2 & 19.4 & 23.8 & 20.9 \\
\hline
\end{tabular}

Continued on next page 


\begin{tabular}{|l|r|r|r|r|r|r|r|r|}
\hline & 1991 & 1992 & 1993 & 1994 & 1995 & 1996 & 1997 & 1998 \\
\hline CIS Countries: & & & & & & & & \\
\hline Armenia & $\mathrm{n} / \mathrm{a}$ & $\mathrm{n} / \mathrm{a}$ & 1077.2 & 729.5 & 62.5 & 35.1 & 29.1 & 31.8 \\
\hline Azerbaijan & $\mathrm{n} / \mathrm{a}$ & $\mathrm{n} / \mathrm{a}$ & 821.0 & 1114.0 & 24.0 & 18.9 & 33.6 & -9.7 \\
\hline Belarus & $\mathrm{n} / \mathrm{a}$ & $\mathrm{n} / \mathrm{a}$ & $\mathrm{n} / \mathrm{a}$ & 1111.0 & 158.4 & 52.4 & 111.4 & 276.0 \\
\hline Georgia & $\mathrm{n} / \mathrm{a}$ & 464.0 & 4319.0 & 2229.0 & 135.2 & 41.9 & 45.5 & -1.2 \\
\hline Kazakhstan & 211.0 & 391.0 & 692.0 & 576.0 & 106.0 & 13.8 & 27.6 & -11.0 \\
\hline Kyrgyzstan & 84.0 & 428.0 & 180.0 & 125.0 & 76.7 & 22.9 & 24.7 & 17.0 \\
\hline Moldova & $\mathrm{n} / \mathrm{a}$ & 361.7 & 320.2 & 115.7 & 65.2 & 15.3 & 34.0 & -7.2 \\
\hline Russia & 125.9 & 642.6 & 416.1 & 166.4 & 125.8 & 30.6 & 28.4 & 21.0 \\
\hline Tajikistan & 68.0 & 579.0 & 1429.0 & 159.0 & 413.0 & 143.0 & 117.0 & 9.0 \\
\hline Turkmenistan & $\mathrm{n} / \mathrm{a}$ & $\mathrm{n} / \mathrm{a}$ & $\mathrm{n} / \mathrm{a}$ & 984.0 & 454.0 & 413.0 & 82.0 & 50.0 \\
\hline Ukraine & $\mathrm{n} / \mathrm{a}$ & $\mathrm{n} / \mathrm{a}$ & 758.0 & 540.0 & 116.0 & 35.0 & 35.0 & 25.0 \\
\hline Uzbekistan & $\mathrm{n} / \mathrm{a}$ & 486.0 & 784.0 & 680.3 & 144.0 & 113.0 & 36.0 & 30.0 \\
\hline
\end{tabular}

Source: EBRD (1999), Transition report: update, London: European Bank for Reconstruction and Development. (* $=$ M1, ** = M2)

However, as Table 6 clearly shows, establishing monetary stability has been made more difficult for the new central banks by two main factors:

1. Budget deficits

2. The dollarisation of the economies

\subsection{Budget Deficits and the Money Supply}

In a cash-based economy where the government has the monopoly over currency issue, printing cash provides a straightforward alternative to raising taxes as a means of financing government spending. In the early years of the reform process, money emission was the primary way in which governments financed the growing gap between government spending and tax revenues. There are essentially three ways of financing government spending:

1. Taxation;

2. printing currency or borrowing from the banking system $æ$ which increase the money supply;

3. borrowing from the general public or abroad æ which increase government debt.

Transition governments have sought to rebuild their tax bases with varying degrees of success and, by western standards, budgets deficits in CEES and 
the CIS are generally modest. Nevertheless, monetary financing of the residual budget deficits remains a problem. The main reason is that, in western countries, budget deficits are normally financed by borrowing from the general public by selling bonds on the stock market $æ$ and stock markets remain generally under-developed in many transition economies. The other alternative, borrowing from abroad, also has its drawbacks. While the IMF and the World Bank have been prepared to extend large loans to transition governments to assist them through the early stages, these loans are highly conditional upon the governments adhering to pre-agreed policies, restricting the government's subsequent room for policy manoeuvre. Unlike sales of bonds to the general public, which are normally in the local currency, governments borrow from the international agencies in foreign currency (usually US dollars) and this must be repaid, imposing a burden in terms of interest and capital payments.

\subsection{Dollarisation}

In a market economy, money performs the functions of a medium of exchange, a unit of account and a store of value. The ability of a currency to perform these functions is undermined by high rates of inflation. Typically, in many transition economies, US dollars first began to circulate as an alternative store of value: individuals would switch their wages from the local currency into dollars and only switch back when they had goods to purchase, preserving the value of their wages in the interim. At higher rates of inflation, the 'menu costs' of continually altering the prices of goods and services becomes intolerable and dollars have been used as the unit of account. Prices in a shop, for example, are shown in dollars and, at the checkout, the till operate converts the prices into local currency at the prevailing exchange rate for payment. Finally, when there is hyperinflation, dollarisation often becomes complete, with goods and services being priced and paid for in dollars.

It is impossible to accurately estimate the volume of dollars (and other hard currencies, notably the deutschmark) in circulation in CEE and the CIS, but the sums are huge. The Federal Reserve Bank, for example, calculates that there are more dollars being used in the region than in the United States. This phenomenon presents major problems for monetary control, since a significant proportion of the 'money supply' is unrecorded and outside the central bank's control. Transition economies which have succeeded in stabilising inflation have, however, been able to reverse the dollarisation of their economies. The normal mechanism is that, as inflation comes under control and real interest rates for deposits in local currency become positive, it becomes more attractive to hold bank deposits in local currency than to hold dollar bills. Individuals begin to sell their dollars to the central bank and there is a virtuous circle, as stabilisation leads to an increase in foreign exchange reserves. 


\section{Microeconomic Reform}

A central planning system subsumes the activities performed in a market economy by:

1. dynamic, profit-seeking firms, which seek out profitable investment and production opportunities

2. open competitive markets, in which domestic and foreign consumers and producers come together to set prices, sales and output

3. the financial system, which channels resources from savers to investors which can earn the highest, risk-adjusted returns.

Building a fully-functioning market economy thus involves: transforming state enterprises into outward-looking, profit-oriented firms; opening up domestic markets to internal and external competition and establishing a banking system and capital market in which funds are allocated on the basis of objective risk assessments and prospective returns, rather than in accordance with the demands of a central plan. Finally, transition requires the establishment of a functioning legal system, to define and protect property rights, clarify ownership and, most importantly, to provide a legal framework which facilitates investment.

Table 7 shows that most of the transition economies have completed (or nearly completed) the comprehensive liberalisation of prices, foreign trade and exchange rates; in almost all countries, small-scale enterprises have been largely privatised. ${ }^{9}$ The difference between the CEE and CIS countries is more stark in the field of large-scale privatisation of SOEs and enterprise restructuring and financial sector reform, where the latter lag markedly.

It is also worth noting that the pace of structural change is beginning to slow as compared with the early 1990s. This is because most of the 'easier' reforms have already been achieved, so that the 'hard core' of tasks that remain, notably the restructuring and privatisation of large, loss-making SOEs and the creation of an efficient financial system, are those that promise to be the most socially or politically painful. It is also, in part, because the governments that were in power in the immediate aftermath of the collapse of communism enjoyed a popular mandate to undertake radical political change; as the social pain of the transition process has mounted, the electorate's willingness to tolerate the further sacrifices necessary to maintain the rate of progress has waned. The blunting of voters' appetite for economic transformation, even in the CEE where progress has been more swift and the beneficial results more tangible and evenly spread, is best illustrated by their growing propensity to elect left-wing administrations pledged to slow the pace of reform in the interest of promoting social harmony. 


\section{Table 7: The Transition Picture in 1998}

\begin{tabular}{|c|c|c|c|c|c|c|c|c|c|c|}
\hline & \multicolumn{4}{|c|}{ Firms } & \multicolumn{3}{|c|}{ Markets } & \multicolumn{2}{|c|}{ Finance } & \multirow{2}{*}{\begin{tabular}{|c} 
Law \\
$\begin{array}{c}\text { Index of } \\
\text { legal } \\
\text { reform }\end{array}$
\end{tabular}} \\
\hline & $\begin{array}{c}\text { Private } \\
\text { Sector } \\
\% \\
\text { GDF }\end{array}$ & \begin{tabular}{|c|} 
Large \\
scale \\
privant.
\end{tabular} & $\begin{array}{c}\text { Small- } \\
\text { scale } \\
\text { privant }\end{array}$ & $\begin{array}{c}\text { Ent. } \\
\text { Restruct }\end{array}$ & $\begin{array}{l}\text { Price } \\
\text { liberal }\end{array}$ & $\begin{array}{c}\text { Trade } \\
\text { and } \\
\text { forex }\end{array}$ & $\begin{array}{l}\text { Comp. } \\
\text { Policy }\end{array}$ & $\begin{array}{c}\text { Bank } \\
\text { reform }\end{array}$ & $\begin{array}{c}\text { Capital } \\
\text { markets }\end{array}$ & \\
\hline $\begin{array}{l}\text { CEE } \\
\text { Countries: }\end{array}$ & & & & & & & & & & \\
\hline Albania & 75 & 2 & 4 & 2 & 3 & 4 & 2 & 2 & 2 & 3 \\
\hline Bulgaria & 50 & 3 & 3 & 2 & 3 & 4 & 2 & 3 & 2 & 3 \\
\hline Croatia & 55 & 3 & 4 & 3 & 3 & 4 & 2 & 3 & 2 & 4 \\
\hline Czech Republic & 75 & 4 & 4 & 3 & 3 & 4 & 3 & 3 & 3 & 4 \\
\hline Estonia & 70 & 4 & 4 & 3 & 3 & 4 & 3 & 3 & 1 & 4 \\
\hline FYR Macedonia & 50 & 3 & 4 & 2 & 3 & 4 & 1 & 3 & 3 & 2 \\
\hline Hungary & 75 & 4 & 4 & 3 & 3 & 4 & 3 & 4 & 2 & 4 \\
\hline Latvia & 60 & 3 & 4 & 3 & 3 & 4 & 3 & 3 & 2 & 3 \\
\hline Lithuania & 70 & 3 & 4 & 3 & 3 & 4 & 2 & 3 & 3 & 3 \\
\hline Poland & 65 & 3 & 4 & 3 & 3 & 4 & 3 & 3 & 3 & 4 \\
\hline Romania & 60 & 3 & 3 & 2 & 3 & 4 & 2 & 3 & 2 & 3 \\
\hline Slovak Republic & 75 & 4 & 4 & 3 & 3 & 4 & 3 & 3 & 2 & 3 \\
\hline Slovenia & 50 & 3 & 4 & 3 & 3 & 4 & 2 & 3 & 3 & 3 \\
\hline \multicolumn{11}{|l|}{$\begin{array}{l}\text { CIS } \\
\text { Countries: }\end{array}$} \\
\hline Armenia & 55 & 3 & 3 & 2 & 3 & 4 & 2 & 2 & 1 & 3 \\
\hline Azerbaijan & 40 & 2 & 3 & 2 & 3 & 2 & 1 & 2 & 1 & 1 \\
\hline Belarus & 20 & 1 & 2 & 1 & 3 & 1 & 2 & 1 & 2 & 2 \\
\hline Georgia & 55 & 3 & 4 & 2 & 3 & 4 & 2 & 2 & 1 & 2 \\
\hline Kazakhstan & 55 & 3 & 3 & 2 & 3 & 4 & 2 & 2 & 2 & 2 \\
\hline Kyrgyzstan & 60 & 3 & 4 & 2 & 3 & 4 & 2 & 3 & 2 & 2 \\
\hline Moldova & 45 & 3 & 3 & 2 & 3 & 4 & 2 & 2 & 2 & 2 \\
\hline Russia & 70 & 3 & 4 & 2 & 3 & 4 & 2 & 2 & 3 & 3 \\
\hline Tajikistan & 20 & 2 & 2 & 1 & 3 & 2 & 1 & 1 & 1 & $\mathrm{n} / \mathrm{a}$ \\
\hline Turkmenistan & 25 & 2 & 2 & 2 & 2 & 1 & 1 & 1 & 1 & $\mathrm{n} / \mathrm{a}$ \\
\hline Ukraine & 50 & 2 & 3 & 2 & 3 & 3 & 2 & 2 & 2 & 2 \\
\hline Uzbekistan & 45 & 3 & 3 & 2 & 3 & 2 & 2 & 2 & 2 & 2 \\
\hline
\end{tabular}

Source: EBRD (1998), Transition report 1998, London: European Bank for Reconstruction and Development. 


\section{Key to Table 7}

\begin{tabular}{|c|c|c|c|c|}
\hline & 4 & 3 & 2 & 1 \\
\hline $\begin{array}{l}\text { large scale } \\
\text { privatisation }\end{array}$ & $\begin{array}{l}\text { more than } 50 \% \\
\text { large enterprise } \\
\text { privatised }\end{array}$ & $\begin{array}{l}\text { More than } 25 \% \\
\text { large enterprise } \\
\text { privatised }\end{array}$ & $\begin{array}{l}\text { privatisation } \\
\text { scheme for large } \\
\text { enterprises about to } \\
\text { be introduced }\end{array}$ & $\begin{array}{l}\text { little or nothing } \\
\text { done }\end{array}$ \\
\hline $\begin{array}{l}\text { small-scale } \\
\text { privatisation }\end{array}$ & $\begin{array}{l}\text { all small enterprises } \\
\text { (eg, shops, } \\
\text { restaurants) } \\
\text { privatised }\end{array}$ & $\begin{array}{l}\text { Most small } \\
\text { enterprises } \\
\text { privatised }\end{array}$ & $\begin{array}{l}\text { significant } \\
\text { proportion of small } \\
\text { enterprises } \\
\text { privatised }\end{array}$ & $\begin{array}{l}\text { little or nothing } \\
\text { done }\end{array}$ \\
\hline $\begin{array}{l}\text { Enterprise } \\
\text { restructuring }\end{array}$ & $\begin{array}{l}\text { corporatisation of } \\
\text { state enterprises } \\
\text { completed }\end{array}$ & $\begin{array}{l}\text { Corporatisation in } \\
\text { progress, but } \\
\text { incomplete }\end{array}$ & $\begin{array}{l}\text { legislative reforms } \\
\text { passed, but not } \\
\text { fully implemented }\end{array}$ & $\begin{array}{l}\text { few reforms } \\
\text { passed }\end{array}$ \\
\hline $\begin{array}{l}\text { price } \\
\text { liberalisation }\end{array}$ & $\begin{array}{l}\text { complete price } \\
\text { liberalisation and } \\
\text { anti-monopoly } \\
\text { controls }\end{array}$ & $\begin{array}{l}\text { Substantial price } \\
\text { liberalisation }\end{array}$ & $\begin{array}{l}\text { price controls } \\
\text { remain for } \\
\text { significant number } \\
\text { of products }\end{array}$ & $\begin{array}{l}\text { most prices still } \\
\text { controlled }\end{array}$ \\
\hline $\begin{array}{l}\text { trade and } \\
\text { foreign } \\
\text { exchange } \\
\text { system }\end{array}$ & $\begin{array}{l}\text { no import/export } \\
\text { quotas or controls, } \\
\text { convertible } \\
\text { exchange rate }\end{array}$ & $\begin{array}{l}\text { Few quotas, near } \\
\text { full convertibility of } \\
\text { exchange }\end{array}$ & $\begin{array}{l}\text { few quotas, but } \\
\text { exchange controls } \\
\text { still in force }\end{array}$ & $\begin{array}{l}\text { widespread } \\
\text { importexport } \\
\text { quotas and/or } \\
\text { exchange controls }\end{array}$ \\
\hline $\begin{array}{l}\text { Competition } \\
\text { policy }\end{array}$ & $\begin{array}{l}\text { signification ant- } \\
\text { monopoly } \\
\text { enforcement }\end{array}$ & $\begin{array}{l}\text { Some enforcement } \\
\text { to control abuse of } \\
\text { market power }\end{array}$ & $\begin{array}{l}\text { basic competition } \\
\text { policy rules and } \\
\text { institutions set up }\end{array}$ & $\begin{array}{l}\text { no competition } \\
\text { policy rules or } \\
\text { institutions }\end{array}$ \\
\hline $\begin{array}{l}\text { Banking } \\
\text { reform }\end{array}$ & $\begin{array}{l}\text { well functioning } \\
\text { banking system }\end{array}$ & $\begin{array}{l}\text { Substantial progress } \\
\text { towards competitive } \\
\text { banking system }\end{array}$ & $\begin{array}{l}\text { interest rates main } \\
\text { means of allocating } \\
\text { credit }\end{array}$ & $\begin{array}{l}\text { little or no } \\
\text { progress }\end{array}$ \\
\hline $\begin{array}{l}\text { capital } \\
\text { markets }\end{array}$ & $\begin{array}{l}\text { functioning, liquid } \\
\text { capital market, with } \\
\text { legal framework } \\
\text { approaching } \\
\text { international } \\
\text { standards }\end{array}$ & $\begin{array}{l}\text { Substantial } \\
\text { issues of shares } \\
\text { by private firms } \\
\text { on capital market }\end{array}$ & $\begin{array}{l}\text { establishment of } \\
\text { capital market and } \\
\text { limited trading }\end{array}$ & $\begin{array}{l}\text { little or no } \\
\text { progress }\end{array}$ \\
\hline $\begin{array}{l}\text { Legal reform } \\
\text { index: rules } \\
\text { on pledge, } \\
\text { bankruptcy and } \\
\text { company law }\end{array}$ & $\begin{array}{l}\text { Comprehensive } \\
\text { legal rules, } \\
\text { independently and } \\
\text { consistently } \\
\text { enforced }\end{array}$ & $\begin{array}{l}\text { Legal rules exist, } \\
\text { but enforcement } \\
\text { patchy }\end{array}$ & $\begin{array}{l}\text { Legal rules are } \\
\text { limited or } \\
\text { contradictory, hard } \\
\text { to enforce }\end{array}$ & $\begin{array}{l}\text { Legal rules very } \\
\text { limited in scope, } \\
\text { unclear and } \\
\text { not consistently } \\
\text { enforced }\end{array}$ \\
\hline
\end{tabular}




\section{Conclusions}

Recent years have witnessed a wave of change in central bank legislation around the world, designed to increase the independence of these institutions. These changes have partly been driven by theoretical advances showing that in a world of forward-looking rational agents, the control of monetary policy by governments which have multiple objectives (e.g., for inflation, growth, interest rates, etc) leads to an inherent 'inflationary bias' which be eliminated by delegating monetary control to an independent central bank mandated to pursue price stability.

The perceived need for structural change in the division of monetary policy making powers has been reinforced by cross-sectional empirical studies showing a negative correlation between the degree of central bank independence and inflation, with demonstrably independent banks like the Bundesbank providing an exemplar. Change has also been hastened by the failure of many governments to credibly pre-commit to non-inflationary policies in other ways, for example by adopting a broad money growth target or an exchange rate peg; in an increasingly deregulated global financial market, governments have accordingly used central bank independence as a way of pledging their anti-inflation resolve and thereby promoting financial stability.

This paper has outlined the broad macroeconomic context within which the reform of central banking is taking place in transition economies generally and the CEE states in particular. In contrast to the relatively modest institutional reforms being undertaken in many developed and developing countries, the construction of independent central banks in transition economies is part of a wider, fundamental restructuring of the economy as a whole. Central banks have had to carved out of the previously unified national banking system and, in addition to establishing monetary stability, have been required to take over the supervision of commercial banking system undergoing privatisation and, in many cases, burdened with non-performing loans to former state enterprises.

Moreover, these reforms to the banking system take place in economies struggling with the heavy costs of economic transition. The collapse of former trading relations, deep slumps in economic activity, widespread poverty and popular hostility to restructuring all militate against the ability of the new central banks to establish anti-inflation credentials. Indeed, in economies historically accustomed to the absence of inflation and unemployment, the new central banks are widely perceived as the agents of recession and economic dislocation. In seeking to sever their ties with government and end automatic financing of budget deficits and soft credits to enterprises, they face levels of public and political pressure unknown in developed countries. 
It is worth identifying some broad implications for policy in the CEE states. First, despite different starting points in terms of economic development, dependency on the former Soviet Union and initial degrees of economic dislocation, the CEE states quickly succeeded in creating a two-tier banking system (ie, with a central bank and a commercial banking system), in which the new central banks have a high degree of legal independence from government. Table 8 shows that compared with the Bundesbank, the CEE4 central banks rate at least as high in terms of 'political independence' (ie, broadly 'goal independence') and almost as high in terms of 'economic independence' (ie, 'instrument independence').

Table 8: Legal Independence of CEE Central Banks

\begin{tabular}{|l|c|c|c|}
\hline & $\begin{array}{c}\text { Political Independence } \\
\text { (scale: 0-10) }\end{array}$ & $\begin{array}{c}\text { Economic Independence } \\
\text { (scale: 0-4) }\end{array}$ & $\begin{array}{c}\text { Sum } \\
(0-14)\end{array}$ \\
\hline National Bank of Poland & 6.5 & 2 & 8.5 \\
\hline Czech National Bank & 6 & 3 & 9 \\
\hline Romanian National Bank & 8 & 0 & 8 \\
\hline Bulgarian National Bank & 8 & 3 & 11 \\
\hline Deutsche Bundesbank & 6 & 3 & 9 \\
\hline
\end{tabular}

As in the case of developing countries, however, de facto independence (as opposed to de jure independence) is compromised in a number of subtle, country-specific ways, including government and/or central bank holdings of stock in commercial banks, a large stock of non-performing commercial bank loans (much of it to state or former state enterprises) and political pressure on the central bank and commercial banks to lend to state enterprises on noncommercial terms.

Establishing the existence of a link between the degree of central bank independence and inflation/output in the transition economies is further complicated by large-scale 'dollarisation', hidden unemployment and undeclared losses in the state sector and a large informal economy. The evidence does support the hypothesis that central bank independence assists in the process of disinflation, but significant central bank reform also tends to be associated with adherence to IMF adjustment programmes and faster economic reforms generally $æ$ both of which are negatively correlated with average inflation.

One of the key policy implications is that building a reputation for behaving independently takes time and that legal reforms, whole a prerequisite, are only a first step. In the early stages, reliance on a visible external discipline, normally 
in the form of an exchange rate target, as opposed to internal monetary or inflation targets is an important way for the new central banks to build their anti-inflation reputation. Given the difficulties of effectively forecasting inflation during an era of institutional and structural change, when money multipliers and the velocity of circulation are hard to predict, an external peg has the additional benefit of providing the private sector with a clearly understandable target.

\section{Endnotes}

${ }^{1}$ F. Kydland and E.C. Prescott, 'Rules rather than discretion: the inconsistency of optimal plans', Journal of Political Economy, 85, 1977, 473-492.

${ }^{2}$ R.J. Barro and D. B. Gordon, 'Rules, discretion and reputation in a model of monetary policy', Journal of Monetary Economics, 12, 1983, 101-121.

${ }^{3}$ A. Alesina, 'Politics and business cycles in industrial democracies', Economic Policy, 8, 1989, 55-98; V. Grilli, D. Masciandaro and G. Tabellini, 'Political and monetary institutions and public finance policies in the industrial economies', Economic Policy, 13, 1991, 341- 392.

${ }^{4}$ R. Bade and M. Parkin, 'Central bank laws and monetary policy', Working Paper, University of Western Ontario, 1988; A. Alesina, and L. Summers, 'Central bank independence and macroeconomic performance: some comparative evidence', Journal of Money, Credit and Banking, 25, 1993, 151-162.

5 A. Alesina, and R. Gatti, 'Independent Central Banks: Low Inflation at No Cost?', The American Economic Review, 85, 1995, 196-211; K. Rogoff, 'The optimal degree of commitment to an intermediate monetary target', Quarterly Journal of Economics, $100,1985,1169-1689$.

6 A. Cukierman, 'Central Bank Strategy, Credibility and Independence: Theory and Evidence', Cambridge, Mass, MIT Press, 1996; A. Cukierman and S. Webb, 'Political Influence on the Central Bank: International Evidence', The World Bank Economic Review, 9, 1995, 397-98; A. Cukierman, S. Webb and B. Neyapti, 'Measuring the Independence of Central Banks and Its Effect on Policy Outcomes', The World Bank Economic Review, 6, 1992, 353-98.

7 K. P. Loungani and N. Sheets, 'Central bank independence, inflation and growth in transition economies', Journal of Money, Credit and Banking, 29, 1997, 381-399.

8 The table includes Slovenia, Croatia and Macedonia, but excludes the other states of former Yugoslavia (Bosnia, Serbia and Montenegro) where war and economic sanctions have so far prevented economic transformation. EBRD, Transition report: update, London: European Bank for Reconstruction and Development, 1999. 